\title{
POSISI NAṢ DALAM IJTIHAD ‘UMAR IBN KHATTṬĀB
}

\author{
Fahmi Jawwas \\ STAIN Datokarama Palu, Jl. Diponegoro No. 23 Palu \\ E-mail: fahmi_jawwas@gmail.com
}

\begin{abstract}
Abstrak. Artikel ini membahas tentang posisi nas dalam ijtihad 'Umar ibn Khațtāb. 'Umar adalah sahabat Nabi yang dikenal memiliki wawasan dan kecerdasan yang tinggi. Beliau dikenal oleh umat Islam sebagai bapak para mujtahid. Keberaniannya dalam berijtihad terkadang melahirkan perdebatan di kalangan ulama. Beberapa kalangan bahkan menilainya lebih mengedepankan pertimbangan kemaslahatan dari pada naṣ. Hal ini disebabkan karena hasil ijtihadnya terkesan-bagi sejumlah orang-bertolak belakang dengan apa yang terdapat dalam naș, baik Alquran maupun Sunnah Rasul. Benarkah 'Umar ibn Khațțab mengesampingkan naș dalam berijtihad seperti tuduhan sebagai ulama? Sementara di sisi lain 'Umar adalah tokoh yang mendapat pengakuan oleh Nabi saw. Akan kecerdasannya dalam memahami agama (Islam). Inilah yang akan dicermati dalam tulisan ini.
\end{abstract}

Abstract. This article discusses the position of the nas in the ijtihad of 'Umar ibn Khațāb. 'Umar is a companion of the Prophet who is known to have insight and intelligence. He is known by Muslims as the father of the mujtahid. Courage in ijtihad sometimes spawned debate among scholars. Some have even considered that aspect of ijtihad put the benefit greater than the nas. This is because the results of ijtihad impressed-for some people-contrary to what is contained in the passage, both the Qur'an and Sunnah. Is it true that 'Umar ibn Khațāo rule out nas in ijtihad such allegations as scholars? While on the other hand, 'Umar was a man who got recognition by the Prophet over his intelligence in understanding the religion (Islam). This is what will be examined in this paper.

Kata kunci: ijtihad, maslahat, naș, fiqh 


\section{PENDAHULUAN}

Sejarah Islam mencatat bahwa diantara sahabat-sahabat Nabi yang selalu membela beliau dalam perjuangan dakwah Islam adalah 'Umar ibn Khațāb. Semua buku-buku yang berbicara tentang sejarah Nabi Muhammad Saw pasti tidak akan pernah luput berbicara tentang sahabat Nabi yang satu ini. Dialah 'Umar ibn Khațtāb adalah anak dari Naufal bin Abdul Uzza Amirul Mukminin Abu Hafsin Al-Qurasyi Al-Adawi Al-Faruk. Beliau memeluk Islam pada tahun ke-enam kenabian Nabi Muhammad saw. Ketika itu umur beliau baru dua puluh tujuh tahun. Beliau adalah salah seorang dari sepuluh sahabat yang dijamin masuk surga dan beliau termasuk ulama besar dari kalangan sahabat ahli zuhud. ${ }^{1}$

Tulisan ini bukanlah bertujuan untuk mengangkat setinggitingginya kemuliaan 'Umar ibn Khaț̣āb terhadap sahabat-sahabat yang lain, Karena sahabat-sahabat Nabi memiliki kemulian yang berbeda-beda yang telah Allah Swt berikan kepada mereka. Tulisan ini sengaja penulis angkat karena ada sebagian kelompok yang menamakan Islam ingin mencari kesalahan, kekurangan bahkan menuduh kepada beliau telah melakukan hal-hal yang bertentangan dengan Naș (Alqurandan Hadis). Apapun yang mereka usahakan dengan niat untuk menghina dan mencela sahabat Nabi ini, pasti akan mengalami kehancuran. Karena seperti yang telah kita ketahui bahwa Allah telah bersaksi dan meridhai kepada para sahabat Nabi dari kalangan muhajirin dan Anshar dalam Alquranyang telah terjaga kesucianya sejak 14 abat.

'Umar ibn Khatțāb adalah orang yang sangat kita hormati dan kita kagumi keilmuannya, apalagi dalam hal istinbat hukum, dan itu merupakan salah satu pujian kepada beliau yang banyak memberikan terobosan-terobosan ijtihad yang memukau para sahabat yang lain dan ulama-ulama dari generasi ke generasi.

'Jalaluddin Al-Sayūtī, Tārikh Al-Khulafā', (Mesir: Mațba‘ah Sa‘adah, 1952), h. 121 
Tidak ada yang meragukan keilmuan dan pengabdian beliau terhadap Islam, kecuali orang-orang yang hatinya memiliki penyakit dengki dan hasud, termasuk mereka para orentalis yang sudah dikenal sering mencari kelemahan-kelemahan Islam dengan mengorek dan mencari-cari kejelekan tokoh-tokoh Islam namun mereka tidak mengetahui hakikat dan kedudukannya. Orang-orang seperti itu tidak mempunyai hati kecuali condong kepada kebencian dan rasa dengki. Yang demikian itu tidaklah mengherankan, sebab jarang ada orang yang terlepas dari rasa dengki terhadap orang lain. Terlebih bila memang orang yang didengki itu mempunyai kedudukan dan martabat serta keutamaan yang mapan seperti halnya 'Umar ibn Khaț̣āb. Banyak manusia yang memusuhinya baik secara terang-terangan maupun sembunyi-sembunyi, hingga akhirnya beliaupun mati terbunuh. ${ }^{2}$

Ruway' Al-Ruhaly salah seorang yang telah melakukan penelitian tentang fiqh Umar telah menulis beberapa pemikiran Umar yang begitu kritis sehingga apa yang beliau pikirkan selalu tepat dan sesuai dengan ayat dan hadis yang akan turun. Itu semua karena keridhaan Allah dan Rasul-Nya kepada beliau dan juga ketekunan beliau untuk selalu hadir pada setiap majlisnya Rasulullah saw.

\section{KESESUAIAN FIQH UMAR DENGAN NAṢ (ALQURAN DAN HADIS)}

\section{Kesaksian Alquran tentang Ilmu dan Ketepatan Istinbāṭ fiqh Umar.}

Para ulama banyak menyebutkan beberapa ketepatanketepatan pemikiran Umar dalam beberapa peristiwa yang diakui oleh Naș Alquran. Hal ini menunjukan bahwa pandangan beliau selalu tepat dalam setiap istinbath dan karena beliaulah sosok ulama pertama yang tidak dapat terkotori oleh apapun. Untuk

${ }^{2}$ Ruway' Al-Ruhaily, Fiqh Umar ibn Khatab Muwazinan bi Fiqh Asyhuri al-Mujtahidīn. Terj. A.M. Basalamah dengan Fiqih Umar, (Cet. 1; Jakarta: Pustaka Al-Kausar, 1994), h. 28 
lebih jelasnya akan dikemukakan beberapa contoh tentang tingginya martabat dan tingginya keilmuan beliau.

Pertama, Umar mengusulkan kepada Nabi Muhammad saw agar sebagian maqām ${ }^{3}$ Ibrahim dijadikan sebagai tempat shalat. maka kemudian Allah menurunkan ayat dalam surat Al-Baqarah ayat 125 yang sesuai dengan pemikiran 'Umar ibn Khațțāb. Firman Allah Taala:

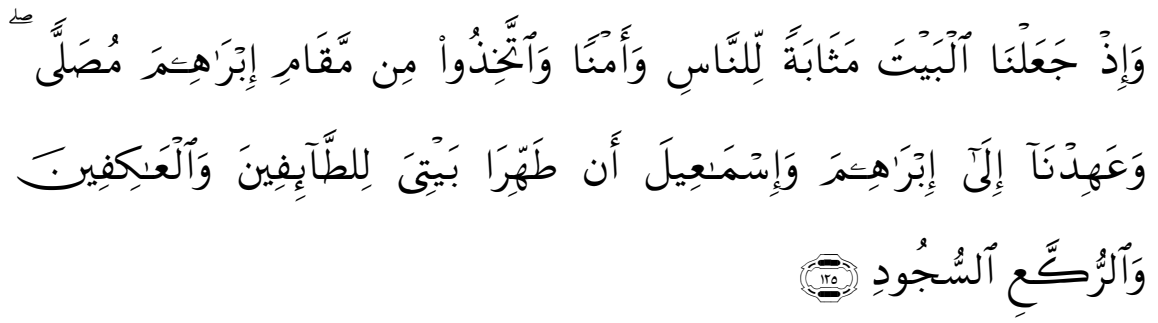

“Dan (ingatlah), ketika Kami menjadikan rumah itu (Baitullah) tempat berkumpul bagi manusia dan tempat yang aman. dan Jadikanlah sebahagian maqam Ibrahim tempat shalat. dan telah Kami perintahkan kepada Ibrahim dan Ismail: "Bersihkanlah rumah-Ku untuk orang-orang yang thawaf, yang i'tikaf, yang ruku' dan yang sujud".

Kedua, Umar mengusulkan kepada Nabi Muhammad Saw, agar istri-istri beliau mengenakan hijab, maka setelah itu Allah menurunkan ayat hijab.

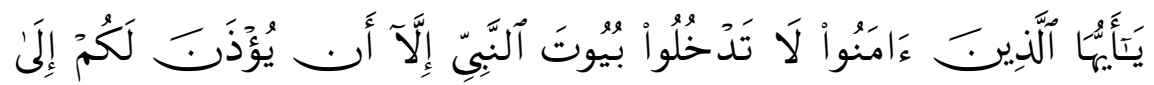

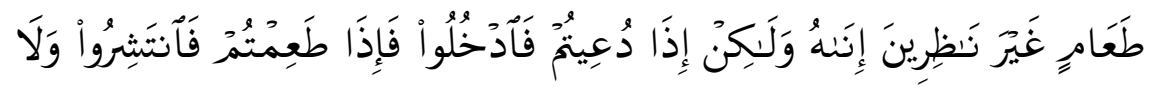

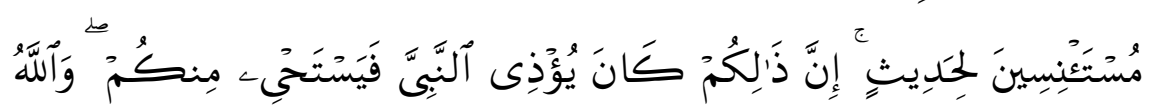

${ }^{3}$ Dalam penjelasan terjemahan Kementrian Agama RI, Maqām Ialah tempat berdiri Nabi Ibrahim a.s. diwaktu membuat Ka'bah.

${ }^{4}$ Lihat Kementrian Agama RI, Alquran dan Terjemahnya, (Jakarta: Proyek Pengadaan Kitab Suci Alquran, 1992), Lihat terjemahan Q.S. Al-Baqarah (2): 125 


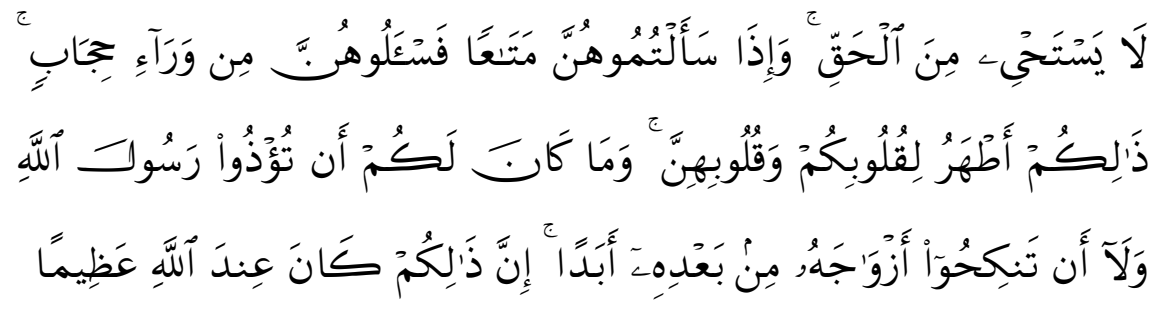

"Hai orang-orang yang beriman, janganlah kamu memasuki rumahrumah Nabi kecuali bila kamudiizinkan untuk makan dengan tidak menunggu-nunggu waktu masak (makanannya), tetapi jika kamu diundang Maka masuklah dan bila kamu selesai makan, keluarlah kamu tanpa asyik memperpanjang percakapan. Sesungguhnya yang demikian itu akan mengganggu Nabi lalu Nabi malu kepadamu (untuk menyuruh kamu keluar), dan Allah tidak malu (menerangkan) yang benar. Apabila kamu meminta sesuatu (keperluan) kepada mereka (isteri- isteri Nabi), Maka mintalah dari belakang tabir. cara yang demikian itu lebih suci bagi hatimu dan hati mereka. dan tidak boleh kamu menyakiti (hati) Rasulullah dan tidak (pula) mengawini isteri- isterinya selama-lamanya sesudah ia wafat. Sesungguhnya perbuatan itu adalah Amat besar (dosanya) di sisi Allah"

Ketiga, Para istri Nabi sedang berkumpul dan saling cemburu, Umar tidak suka melihat hal tersebut, seraya berkata kepada mereka: “ semoga Allah akan menceraikan kalian, lalu menggantinya dengan istri-istri yang lebih baik dari kalian." Kemudian Allah pun menurunkan ayat dalam surat At- Tahrim ayat 5:

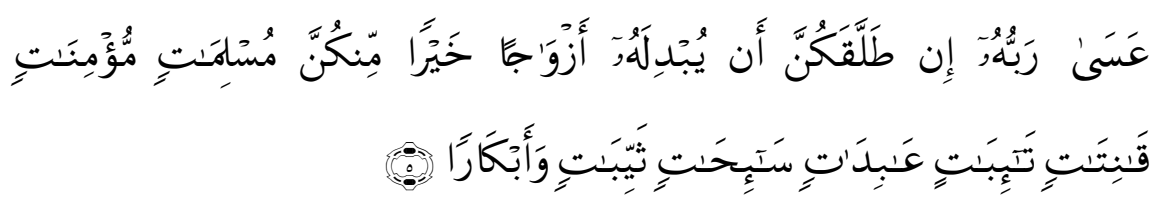

"Jika Nabi menceraikan kamu, boleh Jadi Tuhannya akan memberi ganti kepadanya dengan isteri yang lebih baik dari pada kamu, yang patuh, yang beriman, yang taat, yang bertaubat, yang mengerjakan ibadat, yang berpuasa, yang janda dan yang perawan"

Keempat, Ketika Abdullah bin Ubay bin Salul seorang munafik meninggal, Rasullah menyeru umatnya untuk

${ }^{5}$ Lihat Kementrian Agama RI, Alquran dan ..., Q.S. Al-Tahrim (9): 5. 
menshalatkan jenazahnya. Umar bangkit menghadap Rasulullah Saw seraya memprotes: "Wahai Rasulullah layakkah kita menshalati musuh Allah yang telah berkata ini dan itu pada hari ini ?" belum selesei Umar dalam pembicaraannya seketika itu turunlah wahyu kepada Rasulullah saw sebuah ayat dalam Alquransurat At-Taubah ayat 84:

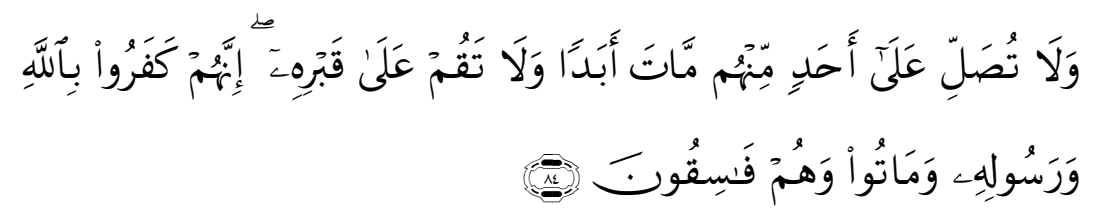

“ Dan janganlah kamu sekali-kali menyembahyangkan (jenazah) seorang yang mati di antara mereka, dan janganlah kamu berdiri (mendoakan) di kuburnya. Sesungguhnya mereka telah kafir kepada Allah dan RasulNya dan mereka mati dalam Keadaan fasik." ${ }^{\prime}$

Kelima, Ketika diturunkan firman Allah kepada Nabi Muhammad saw pada surah Al-Mukminun ayat 14, Umar berkata: "Maha suci Allah Pencipta yang paling baik". Ayat terakhir sesuai dengan apa yang dikatakan oleh 'Umar ibn Khatțāb:

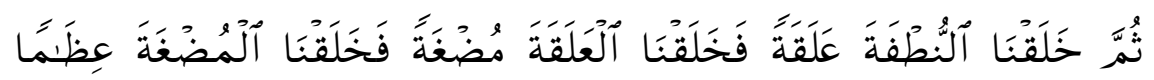

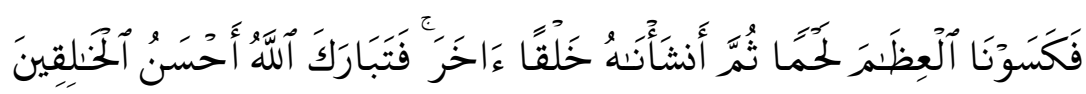

"Kemudian air mani itu Kami jadikan segumpal darah, lalu segumpal darah itu Kami jadikan segumpal daging, dan segumpal daging itu Kami jadikan tulang belulang, lalu tulang belulang itu Kami bungkus dengan daging. kemudian Kami jadikan Dia makhluk yang (berbentuk) lain. Maka Maha sucilah Allah, Pencipta yang paling baik"

Inilah beberapa contoh-contoh kecerdasan ketepatan pemikiran fiqh 'Umar ibn Khațtāb dengan ayat-ayat Alquranyang telah termaktub dalam kitab-kitab tafsir, hukum dan hadis tentang beliau. Bagaimana mungkin ada orang yang berani

${ }^{6}$ Lihat Kementrian Agama RI, Alquran dan ..., Q.S. al-Taubah (9): 84

${ }^{7}$ Lihat Kementrian Agama RI, Kementrian Agama RI, Alquran dan ..., Q.S. al-Mukminun (23): 14 
memojokkan dan menghina beliau dengan berbagai macam tuduhan yang tidak benar. Alqurantelah memberikan kesaksian dan bukti bahwa beliau termasuk sosok manusia yang diridhai Allah dan Rasul-Nya. Terbukti apa yang dipikirkannya dikabulkan oleh Allah dan Rasul-Nya. Ini saja baru sedikit contoh tentang kehebatan keilmuan beliau dalam Alquran. ${ }^{8}$

\section{Kesaksian Sunnah terhadap Ketepatan Pemikiran Fiqh 'Umar ibn Khațțāb}

- Telah diriwayatkan oleh Imam Bukhari dan Imam Muslim dalam kitab mereka yang begitu terkenal kitab Shahih bukhari dan Shahih Muslim bahwa telah Abu Said Al-Khudri r.a bahwa Rasulullah saw telah bersabda:

“ Pada suatu saat aku sedang tidur, aku bermimpi melihat banyak manusia yang menunjukkan kepadaku gamish. Di antantanya ada yang panjang hingga setinggi dada, dan ada pula yang di bawah itu, kemudian Umar menunjukkan kepadaku gamish yang sangat panjang hingga ditariknya: “Apa yang Anda bisa takwilkan (dari mimpi itu ) ya Rasulullah? Beliau menjawab: agama." 9

Al-Syāțibī dalam kitabnya Al-Muwafaqaat mengatakan:

$$
\begin{aligned}
& \text { المفتي قائم في الأمة مقام النبي صلى الله عليه و سلم والدليل على ذلك أمور } \\
& \text { أحدها النقل الثرعي في الحديث أن العلماء ورثة الأنبياء وأن الأنبياء لم يورثوا } \\
& \text { دينارا ولا درهما وإنما ورثوا العلم }
\end{aligned}
$$

“ Bahwa sesungguhnya seorang mufti umat, kedudukannya setara dengan kedudukan seorang Nabi dan dalil atas itu diantaranya Hadis bahwa Nabi Saw bersabda " Sesungguhnya Ulama itu adalah para pewaris nabi ${ }^{10}$.

\footnotetext{
${ }^{8}$ Ruway' Al-Ruhaly, Fiqh Umar ..., h. 34

${ }^{9}$ Lihat Ibnu Hajar al-Aśqalānī, Fatḥ al-Bāri Syarh Șahīh al-Bukhārī, Jilid VII, (t.tp.: Maktabah Al-Mulk Fahd Al-Wataniyyah Asnaa Al-Nasr, t.th.), h. 43.

${ }^{10}$ Al-Syatibi, Al-Muwāfaqāt fĩ Uṣūl Fiqh, Jilid 4, (t.tp.: Dār al-Kitāb, 2008), h. 244
} 
Ruway'I Al-Ruhaylī berkata: “ memberikan komentar tentang pernyataan Imam Al-Syātibī diatas, beliau berkata: “ AlSyāțibī menganggap seolah-olah 'Umar ibn Khaț̣āb telah sampai kepada derajat yang amat tinggi, hingga ia mempunyai hak untuk menjadi seorang mufti bagi umat ini setelah meninggalnya Rasulullah saw". ${ }^{11}$ Jelaslah bahwa Umar memiliki martabat yang tinggi disebabkan banyaknya pemikiran ijtihad beliau yang telah dijadikan rujukan sampai masa sekarang ini. Para ulama dari masa kemasa selalu menjadikan beliau salah satu panutan umat untuk pengembangan figh yang setiap hari mempunyai permasalahan-permasalahan baru yang membutuhkan jawaban yang sesuai dengan kondisi.

- Dalam Hadis Muttafakun Alaihi yang telah disepakati kesahihannya oleh dua ulama ahli Hadis yang terkemuka Imam Bukhari dan Muslim, disebutkan dalam kitab mereka yaitu:

أخرجه البخارى ، ومسلم عن عائشة رضي الله عنها قالت : قال رسول الله

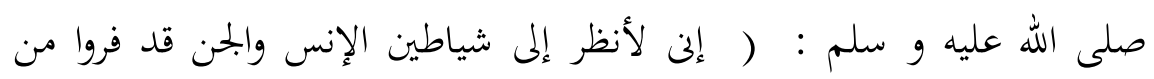

Imam Bukhari dan Imam Muslim telah meriwayatkan: dari Aisyah ra bahwa Rasulullah Saw telah bersabda: “ Sesungguhnya saya melihat bahwa setan-setan jin dan manusia sungguh telah lari dari Umar ". ${ }^{12}$

'Umar ibn Khaț̣āb sangat cerdas dalam mengambil keputusan pada permasalahan yang beliau hadapi. Walaupun beliau menjadi amirul mukminin jabatan yang tertinggi di zamannya, akan tetapi jabatan tersebut tidak menjadikannya sebagai seorang pemimpin yang otoriter dan egois, beliau dengan rendah hati dan tawadhu' selalu menjadikan sahabat-sahabatnya

\footnotetext{
${ }^{11}$ Ruway'l Al-Ruhalī, Fiqh Umar ..., h. 37

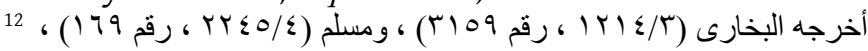


sebagai tempat untuk bermusyawarah dalam masalah-masalah tertentu. Karena sangat takwa dan zuhud, setan-setan lari dan menjauhi 'Umar ibn Khaț̣āb.

- Rasulullah Saw dalam riwayat berkata tentang 'Umar ibn Khatțāb yaitu:

$$
\begin{aligned}
& \text { عن أيوب بن موسى قال رسول الله صلى الله عليه و سلم : إن الله جعل الحق } \\
& \text { على لسان عمر وقلبه وهو الفاروق فرق الله به بين الحق والباطل }
\end{aligned}
$$

"Dari Ayyub bin Musa, bahwa Rasululla Saw berkata: "Sesungguhnya Allah Taala telah menjadikan kebenaran Al-Haq di lisannya Umar dan hatinya, dan dialah Al-Faruq yang telah memisahkan antara yang hak dan yang batil". ${ }^{13}$

\section{Kesaksian Ulama Al-Salaf Al-Șāliḥ atas Tingginya Pengetahuan 'Umar}

Ketika kita membuka kitab-kitab klasik (turaś ) yang telah disusun oleh ulama-ulama generasi terdahulu (al-salaf al-șālih), maka kita akan menemukan pujian dan penghormatan mereka kepada sahabat Nabi yang satu ini. Pujian mereka terhadap Umar merupakan bentuk penghormatan dan penghargaan atas apa yang telah beliau sumbangkan untuk umat ini. Dari berbagai macam ide-ide ijtihad yang merupakan terobosan untuk menjawab segala bentuk masalah-masalah baru dalam kehidupan manusia. Olehnya tidak heran para ulama salaf telah mengakui beliau sebagai bapak mujtahid nomor wahid dalam sejarah pengembangan ilmu fiqh.

Dalam riwayat anaknya sendiri Abdullah ibnu Umar ra, berkata:

"tidak ada masalah apa pun yang terjadi dikalangan masyarakat kemudian mereka berkomentar, kecuali turunlah ayat Alquran yang

${ }^{13}$ Lihat al-Ṭabrānī, al-Mu'jam al-Ausaț, Juz 1, (Beirut: Dār al-Kutub al'Ilmiyah, 1999), h. 354 
menyatakan seperti apa yang telah dikemukakan oleh 'Umar ibn Khatțāb". ${ }^{14}$

Alī bin Abī Ṭālib kw berkata: "Kami para sahabat Rasulullah saw tidak ada yang meragukan bahwa ketenangan jiwa selalu keluar dari mulut 'Umar ibn Khațțāb". ${ }^{15}$

Sahabat Nabi Abu Bakar Al-Ṣiddiq r.a., ditanya mengapa ia mewasiatkan Umar untuk menjadi khalifah sesudahnya, ia menjawab: "Kelak akan aku katakan pada Rab-ku bahwa aku telah meninggalkan seorang khalifah di antara umat Islam seorang yang terbaik diantara mereka" ${ }^{16}$ Abdullah bin Mas'ud ra, berkata: " Kalau saja ilmu Umar ditimbang dengan ilmunya penduduk bumi ini, pastilah akan mereka melihat Umar lebih berat ". ${ }^{17}$ Kalau kita ingin mengemukakan bagaimana keistimewaan 'Umar ibn Khațtāb dalam tulisan ini, penulis yakin halaman ini akan penuh dengan riwayat-riwayat așār dari sahabat tentang sanjungan dan pujian kepada beliau. Oleh karena itu penulis mencucukupkan komentar para sahabat tentang keilmuan Umar dengan kesaksian Nabi Muhammad Saw tentang dua sahabat Nabi yang sangat dimuliakan keilmuannya. Dalam riwayat sahih yang riwayatkan oleh Al-Imam At-Turmuzi bahwa: Sahabat Nabi yang bernama dari Nafi' ra dan dari Ibnu Umar r.a. berkata: “ Bahwa Rasulullah Saw bersabda: "Ikutilah kedua orang ini setelah saya (setelah saya meninggal) yaitu Abu Bakar As-Siddiq dan 'Umar ibn Khatțāb"18. Inilah yang menjadi pernyataan terakhir dari Rasulullah Saw yang menjadi penutup dari sekian banyaknya komentar tentang 'Umar ibn Khațtāb. Pernyataan Rasulullah ini merupakan perintah sekaligus kesaksian beliau tentang kemulian

\footnotetext{
${ }^{14} \mathrm{Abu}$ Ja'far Muhammad ibn Jarir al-Ṭabarī, al-Riyāẹ al-Naḍrah fī Manāqib al-‘Asyrah, Jilid 2, (T.tp.: Dār al-Gharb al-Islāmiy, t.th.), h. 37

${ }^{15}$ Ibid.

${ }^{16}$ Ibid., Jilid 1, h. 321

${ }^{17}$ Ibid., Jilid 2, h. 67

${ }^{18}$ Al-Turmuzī, Sunan al-Turmuzī, (Beirut: Dār al-Kutub al- 'Ilmiyah, t.th.), Hadis yang ke 3662 .
} 
ilmu dan kebenaran ijtihad Umar agar umat Islam menjadikan beliau sebagi sahabat yang harus diikuti.

\section{MANHAJ ISLAM DALAM MEMPERTIMBANGKAN NAȘ DAN $M A Q \bar{A} S I D$}

Sebenarnya kalau kita ingin mengkaji dengan teks-teks agama dengan baik, maka pasti kita tidak akan menemukan sesuatu yang tidak bertentangan antara teks yang satu dengan yang lain, bahkan semuanya saling memberikan jawaban dan saling melengkapi. Oleh karena itu perlu untuk mempertimbangkan antara tujuan-tujuan syariat secara umum dengan teks-teks parsial. Artinya bagaimana kita mengkaji dan melihat teks-teks agama yang bersifat parsial untuk melihat tujuan-tujuan umum syariat Islam. Seorang ulama besar kontemporer yaitu Yusuf Al-Qardawi mengatakan dalam kitabnya Al-Dīn Wa Al-Siyāsah bahwa: dalam hal mempertimbangkan antara naṣ dan maqāșid ada tiga aliran yang harus diketahui yaitu:

Pertama, aliran tekstualis, atau aliran yang Qardawi sebut dengan istilah "Aliran Al-Ẓāhiriyah Modern" yang memusatkan perhatian pada teks-teks yang bersifat parsial dan memahaminya secara tekstual. Mereka hampir tidak menyinggung sama sekali tentang keberadaan tujuan-tujuan syariat, karena itu pandangan mereka selalu bertentangan dengan realita. Mereka juga mempersempit ruang gerak manusia dalam persoalan yang sudah diperluas oleh Allah Swt dan mempersulit persoalan yang sudah dimudahkan oleh-Nya.

Kedua, aliran yang berlawanan dengan aliran pertama. Mereka menafikan adanya teks-teks syariat secara keseluruhan dan sama sekali tidak menghiraukan keberadaan teks-teks tersebut dengan alasan perhatian mereka hanya tertuju pada tujuan-tujuan dan inti syariat. Qardawi menyebut mereka dengan istilah "al-Madrasah al-Mu'âtilah" (aliran yang mengabaikan). Pada masa dahulu ada juga ulama yang disebut dengan al- 
Mu'ațilah, bedanya para ulama tersebut mengabaikan aqidah, sementara aliran ini mengabaikan syariah. Kemudian Qardawi menambahkan "merekalah yang kemudian menghalalkan riba dalam persoalan ekonomi, menghapus hudud dalam persoalan hukuman, mengharamkan cerai dan poligami dalam persoalan perkawinan, menghapus keawajiban berjilbab bagi perempuan dan mengabaikan seruan jihad membela dakwah dan umat Islam. $^{19}$

\section{BENARKAH UMAR MENGABAIKAN NAṢ?}

Setelah penulis mengemukaan keistimewaan dan ketinggian keilmuan 'Umar ibn Khațtāb dan kesaksian Rasul dan sahabat tentang beliau. Maka tentunya para pembaca telah memahami bagaimana kesaksian Rasul dan sahabat tentang beliau sangat luar biasa. Oleh karena itu mustahil 'Umar ibn Khațțāb dalam memimpin umat pernah melakukan suatu yang menyimpang sesuai dengan tuduhan yang mengatakan kepada beliau bahwa beliau mengenyampingkan Naṣ (Alqurandan Hadis) karena maslahat. Beliau dikenal sahabat paling teliti dan memiliki kehatihatian dalam berijtihad tentang kasus-kasus hukum fiqh tertentu.

Karena ini sangat berbahaya dan harus diluruskan tuduhan tersebut. Maka tidak heran para ulama menjawab dan membantah apa yang mereka suarakan. Contoh Dr. Yusuf AlQardawi berkata dan menukil perkataan para pemikir liberal dan sekuler dan para penuduh Umar dalam kitabnya yang berjudul “ Al-Siyāsah al-Syar'iyyah fī Dūi Nușūṣ al-Syar'iyah wa Maqāṣidahä', mereka berkata bahwa: 'Umar telah menāṣakh (membatalkan) teks-teks dalam Alquran yang telah mewajibkan pemberian hak zakat bagi para muallaf sesuai dengan Nas yang pasti (Naș qhati). Firman Allah dalam Alqurandalam surah AtTaubah ayat 60:

\footnotetext{
${ }^{19}$ Lihat Yusuf al-Qardawi, al-Dīn wa al-Siyāsah. Terj. Meluruskan Dikotomi Agama dan Politik (Bantahan Tuntas Terhadap Sekularisme dan Liberalisme”. (Cet. 1; Jakarta: Penerbit Pustaka al-Kausar, 2008), h. 112.
} 


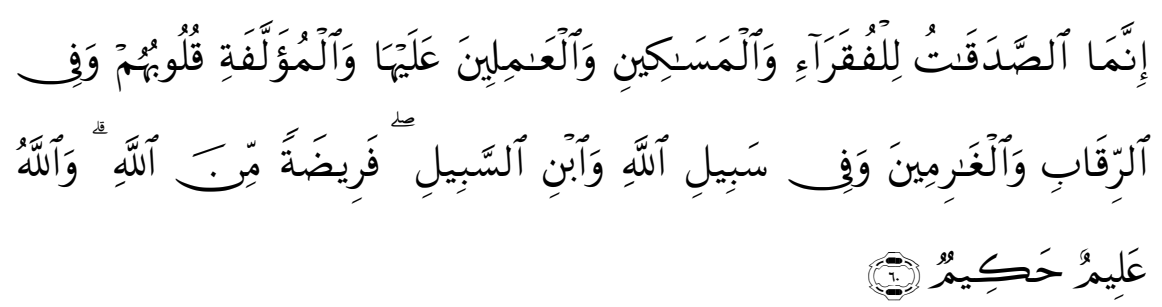

"Sesungguhnya zakat-zakat itu, hanyalah untuk orang-orang fakir, orang-orang miskin, pengurus-pengurus zakat, Para mu'allaf yang dibujuk hatinya, untuk (memerdekakan) budak, orang-orang yang berhutang, untuk jalan Allah dan untuk mereka yuang sedang dalam perjalanan, sebagai suatu ketetapan yang diwajibkan Allah, dan Allah Maha mengetahui lagi Maha Bijaksana". ${ }^{20}$

Al-Qardawi mengatakan bahwa mereka yang telah menyuarakan bahwa Umar telah mengesampingkan Naș karena maslahat adalah mereka yang termasuk dalam deretan namanama (para pemikir liberal dan sekuler diantaranya) adalah Said Al-Asmawi, Nur Farhat, Nasr Hamid Abu Zaid, Said Al-Qumni yang berasal dari negara Mesir dan yang lainnya dari Negara-negara Arab yang lain. Sampai ada diantara para pemikir liberal tersebut berkata yaitu perwakilan dari yordania As-Syaidah Taujan Faisal pada acara seminar yang diadakan pada chanel Al-Jazirah AlQatar tentang hukum poligami, dia berkata bahwa: "Sesungguhnya hukum tersebut telah selesei waktunya dan telah dibatalkan dan kemudian dia menambahkan bahwa hukumhukum dalam Alqurandapat dibatalkan kalau tidak sesuai lagi dengan zaman dan semua yang dia katakan mengikuti caranya 'Umar ibn Khațtāb dalam menghentikan hak pemberian zakat bagi para muallaf yang mana mereka dari zamannya Rasulullah Saw dan Abu Bakar Al-Ṣiddīq mendapatkan hak mereka ${ }^{21}$.

\footnotetext{
${ }^{20}$ Departemen Agama, Alquran dan Terjemahnya, (Jakarta: Proyek Pengadaan Kitab Suci Alquran, 1992), Lihat terjemahan Q.S. al-Taubah (09): 60

${ }^{21}$ Lihat Yusuf al-Qardawi, al-Siyāsah al-Syar'iyyah fī Dūi Nușūs alSyarīah wa Maqāsidihā, (Cet. ke-1; Kairo: Maktabah Wahbah. 1998 M / 1419 H.), h. 174.
} 
Bagaimana mungkin beliau yakni 'Umar ibn Khațtāb melakukan kecerobohan dalam masalah hukum. Untuk menyikapi dan membantah hal tersebut perlu kita mengkaji kembali dan membaca kitab-kitab tentang ijtihad Umar dengan baik dan menjauhkan sikap egois dan subyektif. Penulis akan menberikan contoh-contoh kasus tentang tuduhan mereka terhadap orang yang sangat kita hormati dalam sejarah umat Islam ini. Diantaranya kasus-kasus yang dituduhkan para pemikir liberal, sekuler dan orentalis barat kepada 'Umar ibn Khațtāb adalah:

- Penghapusan pemberian hak zakat kepada para muallaf dalam Alquran

- Penghentian hukum had potong tangan pada tahun maja'ah (kelaparan/ Paceklik)

- Penolakan Umar atas permintaan sahabat untuk membagi tanah-tanah ganimah (hasil rampasan perang).

- Melarang pernikahan laki-laki muslim dengan perempuan ahli kitab.

- Tentang permasalahan talak tiga

- Menambah hukuman bagi peminum khamar

- Menggugurkan kewajiban jizyah terhadap suku Taghlib.

- Menentukan harga pasar.

Sebenarnya masih ada beberapa lagi tuduhan yang dilemparkan kepada beliau dari kalangan orentalis, para pemikir sekuler dan bahkan mereka yang mengaku Islam tapi memiliki pemikiran liberal. Inilah mereka yang tidak mengenal ruh manhaj Islam dengan baik. Sehingga tidak mempunyai dasar yang kuat untuk memahami secara mendalam apa yang dipikirkan oleh sang mujtahid nomor satu itu. Mereka tidak mengenal Umar, bahkan mereka yang membenci beliau hanya mengikuti hawa nafsunya semata. Sehingga buta akan kecerdasan pemikiran fiqh seorang sahabat yang dimuliakan Nabi Muhammad saw ini. Penulis akan 
mencoba menguraikan dan menjelaskan jawaban para ulama kontemporer yang terdapat pada buku-buku yang tersebar di perpustakaan-perpustakaan Islam. Penulis dalam tulisan yang sederhana ini ingin mengupas kembali tentang tuduhan-tuduhan yang dialamatkan kepada seorang tokoh sahabat yang dicintai Rasul dan Umatnya, dialah 'Umar ibn Khațțāb al-Fārūq. Akan tetapi penulis hanya membatasi pada tuduhan pertama yaitu tentang Penghapusan pemberian hak zakat kepada para muallaf dalam Alquran.

Para ulama telah menjawab tentang permasalahan diatas tentang apakah 'Umar ibn Khațtāb telah menghapus Naṣ yang telah memerintahkan untuk memberikan zakat kepada para Muallaf. Disini penulis akan menukil jawaban dari seorang ulama kaliber yang dikenal sebagai mujaddid zaman ini yaitu Dr. Yusuf Al-Qardawi beliau berkata: “ Para pemikir sekuler yang termasuk dalam aliran kedua yaitu aliran yang mengenyampingkan NașNaș agama, mengklaim bahwa 'Umar ibn Khaț̣āb telah mengenyampingkan Naș Alqurandemi maslahat. Kita percaya Umar tidak mungkin melakukannya, karena dia selalu bersandar pada kitab Allah. Diriwayatkan bahwasanya ada seorang perempuan memprotesnya saat ia menetapkan besarnya maskawin. Begitu mendengar protes perempuan yang menukil ayat Alqurantersebut, Umar mencabut keputusannya seraya berkata: "Perempuan itu benar dan Umar yang salah ". Kemudian beliau berkata " Rakyat yang dipimpin 'Umar ibn Khaț̣āb adalah para sahabat Nabi Saw dari kalangan Muhajirin dan Anshar yang telah banyak berjihad baik dengan harta maupun diri mereka. mereka adalah orang-orang yang tidak mungkin membiarkan Umar mengenyampingkan Kitabullah dan mengganti syariat Allah begitu saja. Seandainya Umar melakukannya dan ia tidak mungkin melakukannya, pasti mereka tidak akan menerimanya begitu saja selama jantung mereka masih berdenyut. ${ }^{22}$

\footnotetext{
${ }^{22}$ Yusuf Al-Qardawi, al-Dīn wa al-Siyāsah..., h. 112
} 
Yusuf Qardawi melanjutkan “"Umar dituduh telah menghapus bagian para muallaf yang sudah ditetapkan di dalam Alquran. Tentu saja ini hanya kesalahan pahaman sebagian pemikir dalam mengartikan sikap Umar tersebut. Umar melarang pemberian bagian zakat dan lainnya hanyalah kepada orang yang berstatus sebagai muallaf (orang-orang yang masuk Islam) pada masa Rasulullah Saw dan masa Abu Bakar. Setelah Islam semakin kuat dan jaya. Setelah Islam semakin jaya, Umar melihat bahwa mereka tidak berhak lagi mengambil harta dari Baitul Mal, karena status mereka sudah tidak lagi sebagai muallaf. Umar hanyalah menghapus bagian zakat orang-orang tertentu, dengan demikian, nas mana yang dilanggar oleh Umar? Alquran menyebut bahwa para muallaf berhak menerima harta zakat sebagaimana tujuh kelompok penerima zakat lainnya yang disebutkan salam surat alTaubah. Kita harus ingat bahwa Alquran juga tidak menyebutkan bahwa pemimpin kabilah seperti Uyainah bin Hisn Al-Fazari, AlAqra bin Habis At-Tamimi dan lainnya akan berstatus sebagai muallaf untuk selama-lamanya. ${ }^{23}$

Syaikh Qardawi juga mengutip dari apa yang dikatakan oleh Syaikh al-Madani dalam kitab tersebut menjelaskan bahwa kebijakan Umar tersebut dengan penjelasan ilmiah, tegas dan menggunakan logika ilmu fiqh yang tepat. Pada dasarnya para sahabat yang menyetujui sikap Umar, serta Ulama yang hidup setelah mereka tidak keluar dari lingkaran naș apalagi mengenyampingkannya. Mereka hanya memahami bahwa firman Allah Swt.

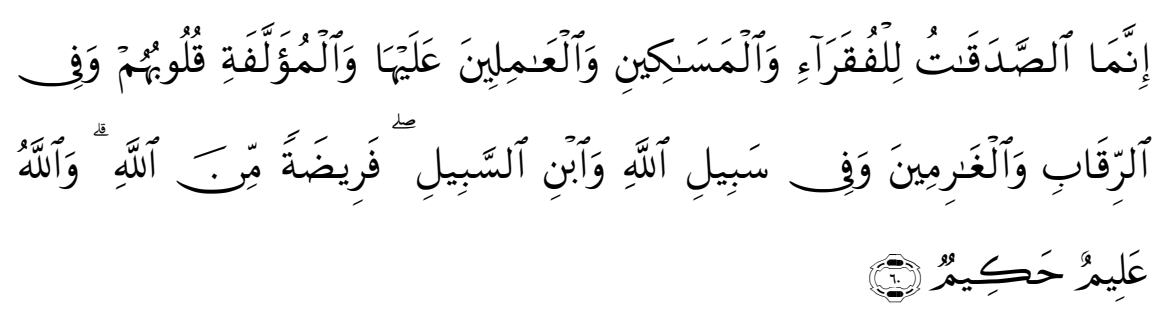

${ }^{23}$ Ibid., h. 117 
"Sesungguhnya zakat-zakat itu, hanyalah untuk orang-orang fakir, orang-orang miskin, pengurus-pengurus zakat, Para mu'allaf yang dibujuk hatinya, untuk (memerdekakan) budak, orang-orang yang berhutang, untuk jalan Allah dan untuk mereka yuang sedang dalam perjalanan, sebagai suatu ketetapan yang diwajibkan Allah, dan Allah Maha mengetahui lagi Maha Bijaksana "24

Yang Artinya: "Para Muallaf yang dibujuk hatinya " adalah menetapkan bahwa ada sekeloompok orang yang berhak mendapatkan harta zakat karena memiliki sifat tertentu. Sifat itulah alasan yang menyebabkan mereka mendapatkan bagian, yaitu karena hati mereka yang harus dibujuk. Namun ketika kondisi telah berubah sebagai sifat-sifat lain yang tidak permanen, pemerintah bisa melakukan peninjauan lagi. Jika benar-benar harus menjadikan mereka sebagai kelompok yang berhak menerima zakat dan mendatangkan maslahat. Maka kelompok ini harus tetap ada. Sebaliknya, jika tidak ada maslahah yang didapatkan sehingga tidak perlu memberikan bagian kepada mereka lagi, maka kelompok ini ditiadakan. Tidak boleh mengatakan bahwa Umar menghapus bagian mereka. Tidak ada

${ }^{24}$ Yang berhak menerima zakat Ialah: 1. orang fakir: orang yang Amat sengsara hidupnya, tidak mempunyai harta dan tenaga untuk memenuhi penghidupannya. 2. orang miskin: orang yang tidak cukup penghidupannya dan dalam Keadaan kekurangan. 3. Pengurus zakat: orang yang diberi tugas untuk mengumpulkan dan membagikan zakat. 4. Muallaf: orang kafir yang ada harapan masuk Islam dan orang yang baru masuk Islam yang imannya masih lemah. 5. memerdekakan budak: mencakup juga untuk melepaskan Muslim yang ditawan oleh orang-orang kafir. 6. orang berhutang: orang yang berhutang karena untuk kepentingan yang bukan maksiat dan tidak sanggup membayarnya. Adapun orang yang berhutang untuk memelihara persatuan umat Islam dibayar hutangnya itu dengan zakat, walaupun ia mampu membayarnya. 7. pada jalan Allah (sabilillah): Yaitu untuk keperluan pertahanan Islam dan kaum muslimin. di antara mufasirin ada yang berpendapat bahwa fisabilillah itu mencakup juga kepentingan-kepentingan umum seperti mendirikan sekolah, rumah sakit dan lain-lain. 8. orang yang sedang dalam perjalanan yang bukan maksiat mengalami kesengsaraan dalam perjalanannya. 
seorang pun yang mengatakan bahwa Umar menghapus begian para muallaf ${ }^{25}$.

Kemudian untuk memperkuat pernyataan Syaick al-Madani, Yusuf al-Qardawi menyatakan "Bantahan yang harus kita katakan adalah bahwa statemen Umar terhadap para muallaf yang mendapatkan bagian zakat pada masa Rasulullah Saw yang berbunyi "Allah sudah memperkuat Islam dan tidak lagi membutuhkan kalian". Maksudnya adalah Rasulullah menundukkan hati (member harta zakat) kepada kalian demi maslahat Islam, karena itu kalian disebut al-Muallafah Qulūbuhum. Tetapi saat ini sebutan tersebut tidak lagi sesuai dengan kalian karena Islam sudah kuat dan cukup. Islam tidak perlu menjadikan muallaf sebagai kelompok yang berhak menerima zakat karena saat ini tidak ada lagi umat yang memiliki sifat al-muallafah Qulübuhum, walaupun sebelumnya mereka disebut dengan nama itu. Sifat itu bisa berubah-rubah seperti fakir, bisa jadi seseorang yang sebelumnya dikatakan fakir dan mendapatkan bagian dari harta zakat, beberapa waktu kemudian ia menjadi kaya, jika demikian halnya, tentu saja ia tidak lagi mendapatkan bagian harta zakat. Jangan berfikir orang tersebut akan mendapatkan bagian zakat sampai akhir khayatnya atau seorang pemimpin harus memberikan zakat kepadanya selama ia hidup. Persoalan ini kembali kepada maslahat sesuai pertimbangan dan kebijaksaan seorang pemimpin. Jika menurut ijtihad pemimpin Negara harus memperhatikan para muallaf, maka mereka berhak menerima zakat, demikian sebaliknya. Jika ada orang yang berusaha membantah sikap Umar r.a. bahwa memberikan bagian khusus kepada para muallaf hukumnya wajib bagi setiap pemimpin dalam keadaan apapun maka perdebatan ini termasuk dalam masalah ijtihad. Bukan masalah naș. Sangat jelas perbedaan antara membentuk kelompok yang disebut dengan alMuallafah Qulūbuhum dengan memberikan bagian harta zakat

${ }^{25}$ Yusuf Al-Qardawi, al-Dīn wa al-Siyāsah..., h. 118 
terhadap mereka jika memang saat itu mereka benar-benar ada . Yang pertama adalah persoalan yang disesuaikan dengan maslahat sehingga akan menghasilkan ijtihad yang berbeda-beda. Sementara yang kedua adalah hukum yang berdasarkan pada Naș dan tidak boleh dilanggar, diubah ataupun dikesampingkan. Demikian penjelasan al-Madani yang dinukil oleh Yusuf AlQardawi dalam kitabnya. Sementara Muhammad Al-Gazali mengomentari pendapat Umar dengan mengatakan "Memahami kebijakan Umar sebagai sikap mengenyampingkan teks Alquranadalah sebagai kesalahan besar, Umar tidak mengkin menghalangi suatu kaum dari bagian zakatnya tetapi naṣ Alquran memang tidak mencakup mereka, bukan karena masa berlakunya nas sudah habis. Umar menolak memberikan harta zakat kepada para pemimpin kaum Badui padahal sebelumnya mereka mendapatkannya karena untuk menenangkan hati mereka atau untuk menjauhkan kejahatan mereka. setelah bisa mengalahkan Kisra dan Qaisar, apakah Islam masih perlu menenangkan hati sekian banyak pemimpin kabilah yang tamak dan sebelumnya disebut muallaf ? Biarkan mereka pergi ke neraka jahim jika mereka tidak mau hidup seperti layaknya kaum muslimin yang lain ${ }^{26}$.

Sebenarnya penulis ingin menjelaskan tuduhan-tuduhan itu sesuai apa yang telah dijawab oleh para ulama-ulama yang memiliki keilmuan yang tinggi. Kemudian masih banyak lagi jawaban-jawaban mereka sebagai bantahan atas tuduhantuduhan tersebut terhadap Umar. Akan tetapi penulis hanya membatasi tuduhan mereka yang berkaitan pada penghapusan hukum zakat atas para muallaf.

\section{PENUTUP}

Membahas tentang keiistimewaan Umar merupakan sebuah kebanggan tersendiri bagi umat Islam. Karena beliau adala tokoh sahabat dalam sejarah perjuangan dakwah Islam yang telah

${ }^{26} I b i d .$, h. 120 
memberikan kunci pembuka ijtihad bagi generasi umat Islam dari zaman kezaman. Beliau telah banyak menyumbangkan pemikiran fiqh yang cerdas yang selalu membuka akal manusia bahwa fiqh itu mengalami perubahan sesuai dengan perkembangan zaman dan tempat. Beliau telah mengajarkan bahwa Islam itu ajarannya tidak kaku, sehingga selalau dinamis sesuai dengan kondisi dan dapat diterima oleh akal yang jernih dan tidak bertentangan dengan fitrah manusia. Oleh karena itu suatu kesalahan besar kalau ada diantara orang yang mengatakan beliau telah mengenyampingkan Naṣ Alqurandan Hadis. Dalam Alquransecara tegas memberikan penjelasan tentang bagaimana sikap kaum muslimin jika mendapatkan masalah hukum. Mereka harus taat kepada Allah Taala dan Rasul dam juga pemimpin mereka (dengan ijtihad serta kebijakan pemimpin

Kajian tentang perjalanan sejarah 'Umar ibn Khațțāb memiliki keistimewaan khusus dan memiliki pembahasan yang panjang dan tajam. Karena beliaulah sahabat Nabi dalam sejarah perjalanan fiqh Islam, telah banyak menyumbangkan gagasangagasan ijtihad yang luar biasa. Beliau dikenal oleh para ulama sebagai Bapak Ijtihad dalam fiqh Islam. Buah dari gagasangagasan ijtihad beliau masuk pada bidang-bidang fiqh Islam. Beliau dalam memimpin umat Islam telah banyak melahirkan pemikiran-pemikiran, misalnya dalam bidang fiqh siyasah (fiqh politik Islam), kemudian dalam fiqh jinayat, fiqh mawaris, fiqh ibadah, dan dalam masalah militer beliau banyak menyumbangkan pemikian yang bersifat ijtihadi yang dapat memberikan kemaslahatan umum, khususnya bagi umat Islam. Walaupun ada juga yang tidak senang kepada beliau dengan beberapa hasil ijtihadnya. Itu bukan menjadikan keilmuan beliau akan turun, justru dengan adanya tantangan dan ujian serta hujatan dari orang-orang yang tidak bertanggungjawab, akan menjadikan beliau semakin Allah angkat derajatnya dan mereka yang menghujatnya semakin Allah rendahkan dimuka bumi ini. 
Fahmi Jawwas, Posisi Naș dalam Ijtihad...

\section{DAFTAR PUSTAKA}

Aṡqalāni, Ahmad bin ali Ibnu Hajar al-, Fath al-Bārī Syarh Șahīh alBukhārī, t.tp.: Maktabah al-Mulk Fahd al-Wațaniyyah Asnā al-Nasyr, t.th.

Departemen Agama RI, Alquran dan Terjemahnya, Jakarta: Proyek Pengadaan Kitab Suci Alquran, 1992.

Qardawi, Yusuf al-, al-Dīn wa al-Siyāsah. terj. Meluruskan Dikotomi Agama dan Politik (Bantahan Tuntas Terhadap Sekularisme dan Liberalisme", Cet. ke-1; Jakarta: Penerbit Pustaka Al-Kausar, 2008.

Qardawi, Yusuf al-, As-Siyasah As-Syariyyah fi dhui Nushus AsSyariah wa Maqasidiha, cet. ke-1; Kairo: Maktabah Wahbah, 1998 M./1419 H.

Ruhaly, Ruway'l al-, Fiqh Umar ibn Khatab Muwazinan bi Fiqh Asyhur al-Mujtahidin. Terj. oleh A.M. Basalamah Fiqh Umar, Cet. 1; Jakarta: Pustaka Al-Kausar, 1994

Sayūțī, Imam Jalal al-Din al-, Tārīkh al-Khulafā', Mesir: Maṭba'ah Sa'adah, 1952.

Syatibī, Abi Ishaq bin Ibrahim bin Musa al-, Al-Muwafaqaat fi Ushul Fiqh, t.tp.: Dār al-Kitāb, 2008

Tabarī, Abu Ja'far Muhammad ibn Jarir al-, al-Riyāẹ al-Naḍah fī Manāqib al-'Asyrah, T.tp.: Dār al-Gharb al-Islāmiy, t.th.

Ṭabrānī, al-Imām Ab̄̄ al-Qāsim Sulaimān ibn Aḥmad ibn Ayyub al-, al-Mu'jam al-Ausat, Beirut: Dār al-Kutub al-'Ilmiyah, 1999

Turmuzi al-, Sunan al-Turmuzī, Beirut: Dār al-Kutub al- 'Ilmiyah, t.th. 